\title{
Nicholas Wapshott, Keynes kontra Hayek. Spór, który zdefiniowat wspótczesna ekonomię, tłum. Radosław Madejski, Wydawnictwo Studio EMKA, Warszawa 2013, s. 423
}

\section{(c) $(1) \ominus$}

DOI: http://dx.doi.org/10.12775/KLIO.2014.016

\section{$\mathrm{H}$}

istorię myśli ludzkiej, w różnych jej dziedzinach i w poszczególnych epokach dziejów, zawsze tworzą giganci. Napisanie ich biografii, złożonych z tysięcy, przeważnie niejednoznacznych faktów, to zadanie heroiczne, a efekt końcowy nie zawsze bywa zgodny z oczekiwaniami i wart niezbędnej w ich wypadku iście „benedyktyńskiej” pracowitości. Mieszkający w Nowym Jorku, wybitny angielski dziennikarz i pisarz Nicholas Wapshott, autor przełożonej na język polski i wydanej w 2013 roku przez Wydawnictwa Studio EMKA książki Keynes kontra Hayek. Spór, który zdefiniowat wspótczesną ekonomię, na pewno swojego czasu nie zmarnował. Jej czytelnicy już po kilku stronach lektury zwrócą uwagę na niezwykłą przystępność wykładu, w którym nawet najtrudniejsze niuanse ekonomii i jej nierzadko skomplikowanych praw - w tym też tych odkrytych czy spopularyzowanych przez dwóch bohaterów jego książki - stają się zrozumiałe. Dodatkowo poznanie życia i poglądów Johna Maynarda Keynesa i Friedricha Augusta von Hayeka ułatwi im samo pióro publicysty, choć uznanie należy się również Radosławowi Madejskiemu, tłumaczowi książki.

Za jeden z niewielu oczywistych mankamentów polskiego wydania książki Wapshotta należy uznać umieszczenie przypisów na końcu, za jeden z licznych atutów zaś - niepominięcie obszernej bibliografii, przy czym autor sięgnął nie tylko do niełatwych w odbiorze dzieł dwóch swoich bohaterów oraz ich kontynuatorów, ale także do wielu innych, wykorzystywanych głównie przez historyków źródeł (np. pamiętników, wspomnień, listów).

Wapshott dokonuje nadzwyczaj udanej prezentacji sporu, który toczy się ponad trzy ćwierćwiecza, od Wielkiego Kryzysu do czasów nam współczesnych i kolejnego już załamania globalnej gospodarki - o reperkusjach chyba nie mniejszych od tego z 1929 roku. Osiemnaście rozdziałów autor 
zatytułował niczym w sensacyjnej powieści, co jednak świetnie oddaje ich pasjonującą treść. Treść pracy została ułożona chronologicznie, co umożliwiło logiczne i przejrzyste opisanie kolei życia oraz ewolucji poglądów dwóch jej nieprzeciętnych bohaterów. Zaprezentowano ich przy tym na barwnym tle tragicznej historii burzliwych dziejów XX stulecia. Zarówno dla wychowanego w jeszcze imperialnej Anglii Keynesa, jak i dla dorastającego w chylącej się ku upadkowi Austrii Hayeka zrozumienie nowych czasów nie mogło być łatwe. Pod względem intelektualnych tradycji i wartości byli oni ludźmi ukształtowanymi jeszcze przez XIX wiek, a przyszyło im przecież tworzyć rzeczywistość już kolejnego stulecia, pod każdym względem (w tym również ekonomicznym) zupełnie odmiennego.

W przypadku tego dzieła raczej niemożliwe jest precyzyjne określenie jego tez. Mamy po prostu do czynienia z biografią dwóch wielkich ekonomistów, która w sposób fascynujący została połączona z rozważaniami na temat ich koncepcji, zaprezentowanymi dodatkowo na tle epoki (czy też raczej epok). Dzięki temu połączeniu staje się ona, chcąc nie chcąc, interesującym podręcznikiem dwudziestowiecznej myśli ekonomicznej, jeżeli nie kompletnym, to na pewno omawiającym jej monetarystyczną część. Autor nie zapomniał też o przedstawieniu naukowej „genealogii" obu badaczy, ukształtowanych przez innych wielkich ekonomistów (np. F. Y. Edgewortha oraz A. Marshalla w przypadku Keynesa, L. von Miesesa w wypadku Hayeka), a także o zaprezentowaniu szerokiego i różnorodnego grona ich uczniów i kontynuatorów (czasem wręcz wyznawców), w tym chociażby tak znanych i wybitnych jak Milton Friedman. Inspirująca w dziele Wapshotta - choć przypuszczalnie bardziej dla historyków niż dla ekonomistów - jest prezentacja dwóch jakże różnych osobowości: dowcipnego, nieraz aroganckiego Keynesa i oschłego, pedantycznego, ale też nieraz dążącego do konfrontacji Hayeka. W tym przedstawieniu dociekań, zachowań, motywów działań i przede wszystkim niełatwych charakterów dwóch najsławniejszych ekonomicznych antagonistów XX stulecia autor chwilami stosuje nawet - i to z pozytywnymi rezultatami - historiograficzny psychologizm. Ciekawe jest także to, że stara się on udowodnić - i to dość skutecznie - że u podstaw wielu pomysłów obu myślicieli tkwił głęboki idealizm (optymistyczny u Kenesa, a pesymistyczny u Hayeka). Skądinąd idealizm ten pozwalał im wierzyć, że ich 
koncepcje będą wprowadzone w życie bez uproszczeń i modyfikacji, co jednak w praktyce okazało się fikcją.

Od lektury pierwszych stron książki brytyjskiego dziennikarza czytelnik zwróci zapewne uwagę na prawie beznamiętny, lecz bynajmniej nie nudny, obiektywizm brytyjskiego dziennikarza. Stara się on bowiem nie opowiadać po żadnej ze stron opisywanego konfliktu; ta cecha jego analizy i narracji może być wzorem dla każdego historyka. Ponieważ jednak nie pomija faktów, nie unika ich interpretacji, musi wielokrotnie stwierdzić, że poglądy Hayeka były bardziej logiczne i spójne. Z drugiej strony, niektóre fragmenty książki pozwalają odnieść wrażenie, że Wapshott jakby nieco żałował, że zabiegi Keynesa „nakłaniania kolejnych rządów [Jej Królewskiej Mości - O. B.] do walki z bezrobociem poprzez zwiększanie wydatków publicznych [...] okazały się bardzo skromne" (s. 116), zapominając przy tym, że prawdziwy dramat zacząlby się wtedy, gdyby został wysłuchany.

Lektura tego dzieła pozwala sformułować tezę, że dla myśli ekonomicznej i samej światowej gospodarki wielkie znacznie miała pierwsza połowa XX wieku. Wprawdzie niektóre nadzwyczaj ważne zmiany gospodarcze, głównie odchodzenie od kanonu wolnorynkowego - ustalonego już ponad sto lat wcześniej przez Adama Smitha - widoczne były już wcześniej, to jednak właśnie w międzywojniu i przede wszystkim wskutek Wielkiego Kryzysu oraz powstania i ekspansji totalitarnych systemów politycznych nastąpił moment ostatecznego odejścia od dotychczas obowiązujących reguł gry ekonomicznej. Dwaj opisywani przez Wapshotta ekonomiści odegrali $\mathrm{w}$ tych procesach olbrzymią rolę, przy czym triumfatorem tego pojedynku okazał się raczej John Maynard Keynes. Wapshott nie pisze tego wprost, ale przecież nie przypadkiem nazwisko Keynesa znajduje się w każdym podręczniku dwudziestowiecznej historii, a nazwisko Hayeka znane jest nieporównywalnie węższemu gronu zawodowych ekonomistów, historyków oraz, głównie prawicowych, ideologów i polityków. Uwaga ta może być zresztą punktem wyjścia do rozważań na zupełnie inny temat: kto pisze szkolne i akademickie podręczniki?

Wydaje się jednak, że autor w zbyt małym stopniu dostrzegł i przeanalizował dwa problemy. Po pierwsze: niewątpliwa „rewolucja” Keynesa uruchomiła lawinę interwencjonizmu państwowego, której nikt już później nie mógł powstrzymać. Po drugie: tragedia współczesnych nam kryzysów 
ma swoje źródło właśnie w ochoczym i mniej lub bardziej zaplanowanym wcielaniu w życie (głównie przez polityków) pomysłów tego brytyjskiego ekonomisty. Poza tym, szukając w dziele Wapshotta inspiracji dla ekonomicznej futurologii, należy pesymistycznie stwierdzić, że raz „zepsutego” wolnego rynku naprawić już nie można, tym bardziej, że żyjące w demokracji społeczeństwa konsumpcyjnie z pewnością nie zechcą wyzbyć się swojego dobrobytu, nawet zdobytego „na kredyt”, który spłacać będą, raczej bezskutecznie, przyszłe pokolenia.

Kenes kontra Hayek to książka bardzo aktualna nie tylko dlatego, że autor swój wykład doprowadza aż do lat współczesnego nam kryzysu. Do takich można ją zaliczyć dlatego, że zaprezentowany w niej spór (a właściwie szereg sporów dotyczących prawdziwych niuansów ekonomii) trwa nadal, znajdując się u podstaw ekonomicznej strony ludzkiej aktywności, chyba nawet w zakresie większym niż w czasach Keynesa i Hayeka. Należy jednak zadać sobie jeszcze pytanie (szczególnie po lekturze końcowych rozdziałów), czy autor dostrzegł, że obecna gospodarka - z właściwie wirtualnym pieniądzem - jest znacznie bardziej skomplikowana i złożona niż ta z czasów Wielkiego Kryzysu przełomu lat dwudziestych i trzydziestych XX wieku lub też czasów bezpośredniego pojedynku Keynesa z Hayekiem. Dzieło Wapshotta aktualne jest również dlatego, że do dziś makroekonomiczne dylematy i dyskusje toczą się wokół pojęć takich jak np. bezrobocie, poziom oszczędności i inwestycji, strategie kredytowe banków, poziom stóp procentowych, polityka banków centralnych czy poziom inflacji.

$\mathrm{Na}$ podstawie jednej z zawartych $\mathrm{w}$ tej książce opinii można się też zastanawiać, czy teoria korzyści krańcowych, którą zresztą za prawidłową uznawali obaj antagoniści, jest całkowicie bezdyskusyjna. Czy rzeczywiście „im większa ilość dóbr, tym mniejszą wartość przedstawiają one w oczach nabywców"? (s. 124). Przeważnie tak jest i na pewno w odniesieniu do sumy wszystkich dóbr, lecz w wypadku gdy pojedyncze towary stają się powszechne, jest ich coraz więcej, stają się modne, wręcz „trendy”, w oczach coraz mniejszej garstki konsumentów, którzy ich jeszcze nie posiadają, nabierają wartości szczególnie dużej, stają się bardziej pożądane niż wtedy, gdy posiadają je tylko nieliczni.

Można również mieć wątpliwości, czy opinie autora, jakoby teorie Keynesa „naprawiły świat” (s. 159), a Hayek był „krótkowzroczny” (s. 176), 
to nie jego (lub tłumacza) przejęzyczenia. Dla wielu współczesnych zwolenników etatyzmu i państwowego interwencjonizmu, którzy nierzadko powołują się na koncepcje Keynesa, może być zaskoczeniem, gdy dowiedzą się z książki Wapshotta, że był on zwolennikiem równowagi budżetowej (s. 161). Jednak już podczas lektury następnej strony mogę czuć zawód, gdy amerykański dziennikarz, pisząc o Keynesie jako zwolenniku podnoszenia cen, nie rozwija tej myśli. A przecież należało tu przynajmniej wspomnieć, że był to klasyczny przykład myślenia z punktu widzenia producenta, a nie konsumenta, dla ogółu znacznie istotniejszego.

Wapshott wspomniał też, że Keynesem kierował idealizm i wiara w człowieka, a jego intencją nie była „ponura i szara wizja przyszłości, w której swobody osobiste zginą w natłoku odgórnych przepisów” (s. 179). $\mathrm{Z}$ tą opinią autora należy się zgodzić, chociaż szkoda, że nie poświęcił on trochę uwagi przypomnieniu kolejnych dziesięcioleci, w których praktyka udowodniła, że intencje i rzeczywistość nie zawsze bywają kompatybilne. Keynes okazał się naiwny, gdy sądził, że po okresie „sterowania” gospodarką, zażegnania kryzysu i likwidacji masowego bezrobocia powrót do wolnego rynku i reguł klasycznej ekonomii będzie czymś oczywistym. Wapshott jakby tej naiwności nie dostrzegł, Hayek zaś dostrzegł na pewno. Jednak pisząc o początkach praktycznego zastosowania pomysłów Keynesa, autor potrafi logicznie i nieco ironicznie przyznać, że to, co

wyszło na jaw później, dowiodło, że jakkolwiek rewolucja keynesowska z powodzeniem natchnęła administrację Roosevelta ideami interwencjonizmu, nazbyt łatwo mogła zakłócić delikatny proces odnowy amerykańskiej gospodarki (s. 201).

Na pewno należy też pochwalić Wapshotta za przypomnienie niezwykle istotnej opinii Hayeka, że

socjalizm i nazizm nie stanowiły skrajnych przeciwieństw [...], ale były niemal identyczne w swoim stosunku wobec wolnego rynku, ograniczając swobody będące podstawą wolnego społeczeństwa (s. 172).

Jest to tym ważniejsze, że dzisiaj wielu komentatorów przeszłości przemilcza fakt, że Trzecia Rzesza była państwem nie tylko „narodowym”, ale 
również „socjalistycznym”. W związku z tym można mieć wątpliwości co do opinii autora (s. 228), że w Drodze do zniewolenia Hayek uznał nazizm i faszyzm za ideologie lub ruchy „prawicowe”. Odnosząc się do tego najsławniejszego dzieła austriackiego myśliciela, Wapshott zaskakuje informacjami o tym, że tak wybitny umysł jak Keynes z jego treści i przesłania zrozumiał niewiele. Przypomina on też o negatywnych opiniach na temat Drogi do zniewolenia w środowiskach akademickich Stanów Zjednoczonych, równocześnie jednak w niewielkim stopniu wyjaśniając źródła niechęci do pracy, która wszakże miała charakter traktatu bardziej politologicznego niż ekonomicznego. Mało wspomina o prawie powszechnej w tych latach (a także później) wśród amerykańskich intelektualistów „chorobie lewicowości”, na dodatek nierzadko wspieranej finansowo przez Moskwę. Analizując amerykańskie elity lat bezpośrednio powojennych, przypomina jedynie bardzo łagodną opinię samego Hayeka - bądź co bądź dobrze wychowanego Austriaka - że właściwie „ogarnął [je] szał kolektywizmu” (s. 240).

Prawie dla każdego czytelnika książki Keynes kontra Hayek cenne może być poznanie rozważań autora na temat wieloznaczności słowa „liberalny”, „liberalni ekonomiści” to bowiem za Atlantykiem ktoś zupełnie inny niż tzw. liberałowie, których „poglądy na ekonomię nie miały w sobie nic liberalnego” (s. 247). Również obecnie wielu polityków czy dziennikarzy w tym także w Polsce - nie dostrzega lub nie rozumie tego semantycznego niuansu.

Jeden z rozdziałów (15) został poświęcony prezentacji przygnębiających faktów dotyczących działań kontynuatorów myśli Keynesa. Nie brak w nim tyleż inteligentnych, ile ironicznych uwag Wapshotta o tym np., że po wojnie „nikomu nie przyszło przez myśl, by Niemcom, Japończykom czy Włochom przywrócić wolny rynek” (s. 267) albo „Makroekonomia, nowa posępna gałąź nauki mimowolnie wynaleziona przez Keynesa, stała się oficjalnym narzędziem w rękach rządu Stanów Zjednoczonych” (s. 270-271).

Wielokrotnie i trafnie zauważa Wapshott - przede wszystkim na przykładzie powojennych inicjatyw i pomysłów gospodarczych rządów Stanów Zjednoczonych - że keynesizm stał się niezwykle przydatnym narzędziem w rękach wielu polityków funkcjonujących w demokracjach i walczących o głosy wyborców. Przy tym chyba zbyt ogólnikowo wspomina on kilka- 
krotnie, że podwyższenie podatków nie jest równoznaczne ze wzrostem wpływów do państwowych budżetów. Wprawdzie pojawia się w jego książce wątek „krzywej Laffera” (s. 307-308), ale raczej w kontekście zauważenia tej zależności już przez Keynesa. A ma ona dla zrozumienia całego tytułowego „sporu” znaczenie niewspółmiernie większe.

Czasami Wapshott bywa niekonsekwentny w swoich sądach. Pisze mianowicie, że dobrobyt rosnący $\mathrm{w}$ latach sześćdziesiątych XX wieku w Ameryce był efektem keynesowskiego planowania (s. 282), by już na następnej stronie znacznie trafniej stwierdzić, że było to po prostu związane z rosnącym deficytem w budżecie USA. Można też wątpić, czy stagflacja w gospodarce tego mocarstwa już w latach siedemdziesiątych „załamała keynesizm" (s. 289) - choć na pewno mocno osłabiła jego prymat, utrzymujący się przez prawie cztery dekady, i pewność siebie jego zwolenników. Z drugiej strony opisywany przez Wapshotta wzrost w tym okresie popularności teorii Hayeka, a także Friedmana, chyba jednak wcale nie był aż tak duży i bezdyskusyjny.

Niektóre tezy Wapshotta należy uznać za bardzo śmiałe i kontrowersyjne, ale przeważnie są one logicznie uargumentowane. Przykładem może być zaskakujące uznanie reaganoekonomiki za wykorzystanie wskazań nie tyle Hayeka i Friedmana, ile Keynesa (s. 310-311), a z drugiej strony - i również wbrew powszechnie panującym opiniom - polityki gospodarczej demokraty Billa Clintona za czerpiącą dużo inspiracji z idei i pomysłów Hayeka (s. 322-323). Jednocześnie można powątpiewać czy w latach 1980-2008 keynesizm znalazł się w aż takim odwrocie, jak to ukazuje Wapshott. W Stanach Zjednoczonych jego wpływy (chyba bardziej ideologiczne niż praktyczne) z pewnością były mniejsze niż przez poprzednie powojenne dekady, lecz przecież ingerencja państwa w różne dziedziny życia była nadal znacząca, a jej likwidacja była utopią. Politycy nie chcieli rozstać się z raz uzyskaną prerogatywą i równocześnie z wielką pokusą nieustannego działania (przeważnie nieudolnego) na polu gospodarczym, a przede wszystkim dysponowania gigantycznymi budżetami. Odnosząc się do rządów Georga W. Busha, Wapshott sięga po ciekawy, a niepozbawiony ironii cytat z Herberta Steina: 
Radykalna rewolucja konserwatywna jest marzeniem konserwatystów bez stanowisk, ale nie należy do praktyk konserwatystów sprawujących urzędy (s. 326).

Kolejna kontrowersyjna opinia Wapshotta dotyczy genezy współczesnego nam kryzysu. Czy rzeczywiście „finansowy chaos”, który wówczas się rozpoczął, był skutkiem tego, „że prowadzony od dziesiątków lat eksperyment, w którego ramach pozwolono, by prawie wolny rynek tworzył postęp i dobrobyt, okazał się chybiony” (s. 327)? A może owego „wolnego rynku” było zbyt mało? Sam autor zresztą zauważa, że był on tylko „prawie zupełnie wolny”. Przecież za ten kryzys, który gnębi świat już od kilku lat, trudno winić wolny rynek. U jego źródeł znajduje się raczej nieodpowiedzialna polityka banków, następnie naprędce i mało skutecznie ratowanych przez państwowe interwencje. Autor przy tym trafnie konkluduje, że zastosowanie w zwalczaniu tego kryzysu starych metod Keynesa okazało się nieskuteczne.

Wiele interesujących opinii i konkluzji zawartych zostało w ostatnim, osiemnastym rozdziale, w którym autor już w tytule obiecał podjęcie próby wskazania zwycięzcy sporu Keynes kontra Hayek. Pomimo znów pasjonującego, pouczającego i świetnie napisanego wykładu przynajmniej kilka sądów może wywołać dyskusje. Na przykład sprzeciw niektórych czytelników wywoła opinia, że apokaliptyczne wizje Hayeka były „niesprawiedliwe wobec łagodnych socjaldemokratycznych rządów powojennej Europy" (s. 337). Rządy te wprawdzie nie zakładały obozów pracy, ale chociażby przymusowa sterylizacja (wyłącznie na podstawie urzędniczych decyzji) niepełnosprawnych intelektualnie i kosztownych dla podatników osób rozwijała się na olbrzymią skalę (i to do lat siedemdziesiątych XX wieku). Wielu czytelników zada też zapewne pytania, czy „sympatie austriackiego myśliciela” można nazwać „anarchistycznymi” (s. 335) oraz czy jego liberalizm to rzeczywiście „utopia” (s. 339)? W tym drugim przypadku trzeba przecież pamiętać, że w czasach przed Keynesem gospodarka kapitalistyczna była właściwie taka, jaką wymarzył i propagował Hayek, a rozwijała się ona wówczas (np. do 1914 r.) nieporównywalnie szybciej niż kiedykolwiek później. Na podstawie niektórych rozważań z końco- 
wych fragmentów książki można Wapshottowi zarzucić nawet częściowy brak logiki. Pisze on, że

powszechne mniemanie, że z czasem wolny rynek zawsze sam wraca do normy, okazało się tak błędne, iż nie dano mu już drugiej szansy (s. 343),

a nie zadaje pytania, jak miał wrócić, jeżeli w praktyce prawdziwie wolny rynek już od dawna nigdzie nie funkcjonował. Zauważył to zresztą pod koniec swojego długiego życia sam Hayek, który nawet odważne oraz pozytywnie przez niego oceniane inicjatywy Margaret Thatcher i Ronalda Reagana uznał za jedynie „połowiczne”.

Należy się natomiast zgodzić z Wapshottem, gdy stwierdza, że w XXI stuleciu w demokratycznych państwach wprowadzenie w życie wolnościowych koncepcji Hayeka jest już chyba niemożliwe. W ostatnim rozdziale znów sprawiedliwie - co wzbudza podziw - obdziela on krytyką obu wielkich adwersarzy, przy czym jednak zaprezentowana na ostatniej stronie książki opinia, że Keynes „na przestrzeni 80 lat ocalił kapitalizm dwukrotnie" (s. 345), może wywołać raczej uśmiech. Najbardziej wypada żałować, że w tym rozdziale autor nie odpowiedział wprost na pytanie, kto jest (lub też kogo on uznaje) zwycięzcą tego największego ekonomicznego sporu ostatniego stulecia. W zamian sprawnie diagnozuje on zarówno sukcesy, jak i klęski obu myślicieli. Być może istota ich sporu jest najzwyczajniej do dziś nierozstrzygnięta i niemożliwa do ostatecznego rozsądzenia. Czymś innym jest jednak odpowiedź na pytanie, kto ten spór wygrał, a czymś innym i może istotniejszym - ustalenie, kto właściwie miał w tym sporze rację. Autor na ten temat pisze niewiele, choć wielokrotnie stara się nieco asekuracyjnie (jakkolwiek można byłoby to znów oceniać jako obiektywizm) wymieniać niewątpliwe racje, jak i wytykać błędy obu myślicieli. Poza tym po lekturze nasuwa się jeszcze jeden niedostrzeżony przez Wapshotta wniosek: ekonomia ma wiele niuansów i chyba jeszcze dużo kwestii nie zostało w niej jednoznacznie wyjaśnionych. Keynes i Hayek starali się udowodnić naukowo swoje teorie i wyjaśnić je racjonalnie, a przecież leżące u podstaw całej ekonomii ludzkie działania (zarówno grupowe - całych społeczeństw - jak i jednostkowe - poszczególnych osób) bardzo często bywają całkowicie irracjonalne. 
Resumując, mogę stwierdzić, że książka Nicholasa Wapshotta to lektura obowiązkowa dla ekonomistów, gdyż bez dokładnego poznania i zrozumienia istoty opisywanego $\mathrm{w}$ niej najważniejszego sporu w dziejach całej ekonomii nie będą mogli poważnie zajmować się ani teoretyczną, ani praktyczną stroną swojej dyscypliny naukowej. Dla historyków jest zaś godna polecenia przede wszystkim z racji metody, stylu wykładu i zaprezentowania interesującego sposobu opisania dwóch „równoległych” biografii.

Olaf Bergmann (Poznań) 